\title{
DISTRIBUSI GEOGRAFIS TUNGAU PARASIT NYAMUK Aedes sp. DI DAERAH ENDEMIS DEMAM BERDARAH DENGUE DI KABUPATEN BANJARNEGARA
}

\author{
Arthur Shepta LaKsono, BAmbang Heru Budianto, EndANG ARIYANi SETyowati
}

Fakultas Biologi, Universitas Jenderal Soedirman, Jalan dr. Suparno 63 Purwokerto 53122

\section{A B S T R A C T}

Parasitic mites are known as the natural enemy of Aedes sp. that can potentially infect any life stages of the Aedes sp. The parasitic mites' ability to infect Aedes sp. influence the distribution pattern of parasitic mites. The widespread distribution of Aedes sp. is expected to affect the distribution of parasitic mites. The aims of this study were to determine the taxonomic family of parasitic mites that infected Aedes sp. larvae and to determine the geographical distribution patterns of parasitic mites of Aedes sp. in the endemic area of Dengue Hemorrhagic Fever (DHF) in Banjarnegara District. This study used larvae of Aedes sp. taken from the endemic area of DHF in Banjarnegara District. The study sites were in the Parakancanggah Village, Kutabanjar Village, Krandegan Village, and Sokanandi Village. This study used survey method with purposive sampling technique. Variable observed in this research was the distribution pattern of the parasitic mite of Aedes sp. larvae. Parameter observed included the family and the individual number of parasitic mites on each mosquito larvae, the average value, and the variance. Data were analyzed using mean value and the variance so that the distribution pattern can be determined. The level of parasitic mites' distribution was analyzed using $\mathrm{K}^{\prime}$ index negative binomial distribution. Results showed that 30 individual of parasitic mite were found from 1429 samples of examined Aedes sp. larvae. The identification result were five families of parasitic mites: Pionidae, Histiostomatidae, Hydryphantidae, Hydrachnidae, and Arrenuridae. The distribution pattern of the parasitic mites was regular, and the highest value of $K^{\prime}$ index negative binomial distribution was 1,3225, in the Krandegan Village.

KEY WORDS: Distribution Pattern, Aedes sp. Pionidae, Histiostomatidae, Hydryphantidae, Hydrachnidae, Arrenuridae

Corresponding Author: BAMBANG HERU BUDIANTO | email: bhbudianto@gmail.com

\section{PENDAH UL UA N}

Demam berdarah dengue merupakan penyakit yang melibatkan tiga organisme yaitu, virus Dengue, nyamuk Aedes sp., dan manusia. Di Indonesia ada tiga jenis nyamuk Aedes sp. yang bisa menularkan virus Dengue yaitu: A. aegypti, A. albopictus dan A. scutellaris (Nilamsari, 2005). Nyamuk Aedes sp. secara bioekologis mempunyai dua habitat yaitu aquatic untuk fase pradewasanya (telur, larva dan pupa), dan daratan atau udara untuk fase dewasa (imago) (Supartha, 2008).

Fase pertumbuhan nyamuk Aedes sp. sebagian besar berada di habitat aquatic yang dipengaruhi oleh air yang ada di dalam kontainer, air di dalam kontainer biasanya terdapat patogen dan parasit yang akan mempengaruhi pertumbuhan larva tersebut. Tungau merupakan salah satu parasit yang berpotensi menginfeksi di setiap stadium nyamuk Aedes sp (Sukamto, 2007). Sebagian besar tungau dewasa hidup bebas, namun sebagian larva tungau hidup parasit pada arthropoda, termasuk nyamuk (Mullen \& Gary, 1975). Menurut Williams \& Proctor (2002), tungau parasit yang memparasiti nyamuk termasuk dalam familia Hydryphantidae, Arrenuridae dan Erythraeidae. Tungau pararasit ini dapat menembus exoskeleton inang dan memakan hemolymph dan jaringan disekitarnya (Smith \& Mciver, 1983).Kemampuan menginfeksi tungau parasit terhadap inangnya dipengaruhi oleh faktor lingkungan seperti temperatur, ketinggian tempat, $\mathrm{pH}$ air, curah hujan, variasi musim dan ketersediaan tempat perindukan nyamuk (Arrimoro, 2010).
Menurut Bohanak et al. (2004) dalam Budianto (2007) menyatakan bahwa karena sifat tungau parasit yang obligat maka kemampuan menemukan dan menginfeksi jenis Aedes sp. yang lain harus tinggi. Kemampuan menemukan dan menginfeksi tungau parasit terhadap Aedes sp. serta meluasnya distribusi geografis nyamuk Aedes sp. memungkinkan mempengaruhi pola distribusi tungau parasit. Pola distribusi adalah pola pemencaran tata ruang individu yang satu terhadap yang lain dalam suatu populasi. Pola distribusi dalam hal ini merupakan distribusi tungau parasit pada nyamuk Aedes sp. yang dapat tersusun dalam tiga pola dasar, yaitu acak, teratur dan mengelompok (Deshmukh, 1992).

Faktor lingkungan seperti temperatur, kelembaban udara, $\mathrm{pH}$ air, curah hujan, musim mempengaruhi pola distribusi tungau parasit. Selain faktor abiotik, faktor biotik beberapa interaksi mungkin penting dalam menjelaskan pola distribusi tungau parasit. Kehadiran inang yang cocok untuk larva tungau parasit adalah salah satu faktor utama dalam menjalankan siklus kehidupan dan mempengaruhi pola distribusi tungau parasit (Sabatino et al., 2004).

Adapun distribusi tungau dan spesies parasitik pada umumnya tergantung pada umur spesies parasit tersebut, kemampuan suatu parasit untuk berpisah dari inangnya dan daya tingkat keterikatan inang pada habitat tertentu (Elmer \& Noble, 1982). Distribusi tungau juga ditentukan oleh filogeni inangnya, kemampuan pemilihan lokasi sebaik mungkin pada bagian dari tubuh inangnya sehingga dapat memperoleh kebutuhan makanan dan bereproduksi maksimum dalam batas tertentu yang 
ditentukan oleh metabolisme tungau parasit dan respon fisiologi inangnya (Elmer \& Noble, 1982).

Berdasarkan pemikiran tersebut maka tujuan dari penelitian ini adalah untuk: mengetahui Familia tungau parasit yang mempunyai kemampuan menginfeksi nyamuk Aedes sp. di daerah endemis DBD di Kabupaten Banjarnegara, dan menentukan pola distribusi geografis tungau parasit nyamuk Aedes sp. di daerah endemis DBD di Kabupaten Banjarnegara.

\section{METODA}

Penelitian ini menggunakan metode survey dengan teknik pengambilan sampel secara purposive sampling. Pemilihan Kelurahan Parakancanggah, Kelurahan Kutabanjar, Kelurahan Krandegan dan Kelurahan Sokanandi sebagai wilayah sampling didasarkan atas endemisitas DBD. Sampel larva nyamuk Aedes sp. diambil dari empat kelurahan yang merupakan daerah endemis DBD di Kabupaten Banjarnegara. Masing-masing Kelurahan dipilih 120 rumah dari 12 RT yang jumlah kasus DBDnya tertinggi di dalam 3 RW yang paling endemis DBD. Pengambilan sampel akan dilakukan pada beberapa tempat seperti bak mandi, tempayan, pohon berlubang, kaleng bekas dan ban bekas yang tergenangi air (TPA dan non TPA).

Larva nyamuk Aedes sp. ditangkap secara langsung dengan menggunakan jaring kecil ukuran 1x1 mm pada tempat perindukan nyamuk, seperti bak mandi, tempayan, pohon berlubang, drum bekas, kaleng bekas yang tergenangi air baik di dalam rumah maupun yang terdapat di luar rumah pada empat lokasi yang telah ditentukan yaitu Kelurahan Parakancanggah, Kelurahan Kutabanjar, Kelurahan Krandegan dan Kelurahan Sokanandi Kabupaten Banjarnegara. Masing masing Kelurahan tersebut dipilih 3 RW yang paling endemis DBD, dan masing masing Rw dipilih 4 RW yang jumlah kasus DBDnya tertinggi, serta masing masing RT dipilih 10 rumah yang sanitasinya kurang baik. Larva nyamuk Aedes sp. yang tertangkap dipindahkan ke dalam toples transparan yang penutupnya diganti dengan kain kasa untuk memberikan oksigen pada larva. Toples tersebut kemudian dibawa ke laboratorium. Larva nyamuk yang terdapat dalam toples dipindah ke obyek gelas cekung dengan pipet tetes dan diamati di bawah mikroskop binokuler dengan perbesaran 100x. Tungau parasit yang diperoleh, diambil menggunakan insect forceps dan dimasukkan ke dalam obyek glass cekung berisi alkohol $70 \%$ selama kurang lebih lima menit untuk tujuan preservasi. Jenis dan jumlah individu tiap jenis tungau parasit yang diperoleh digunakan untuk menentukan jenis tungau parasit paling banyak menjadi parasit larva Aedes sp.

Identifikasi tungau parasit dilakukan dengan cara sebagai berikut : tungau yang telah didapat dan sudah berada dalam object glass cekung berisi alkohol $70 \%$ didiamkan selama lima menit dengan tujuan mematikan tungau tanpa merusak bagian tubuhnya. Tungau yang telah mati, dipindah ke dalam object glass cekung yang berisi larutan laktofenol untuk tujuan maserasi kurang lebih selama satu minggu sehingga terlihat transparan. Tungau yang telah di maserasi dipindahkan ke object glass datar dan ditetesi larutan Hoyer's untuk proses mounting yang bertujuan untuk pengawetan. Proses tersebut menghasilkan tungau parasit transparan yang memperlihatkan bentuk dan letak setae yang jelas. Proses identifikasi dilakukan dengan menggunakan buku identifikasi Pesic (2003) dan Gerecke (2004). Identifikasi tungau parasit dalam penelitian ini hanya sampai pada tahapan familia.
Penghitungan distribusi tungau dilakukan setelah pengidentifikasian tungau yang diperoleh dari larva nyamuk Aedes sp. Setelah identifikasi tungau parasit, dicatat banyaknya individu setiap jenis tungau parasit yang diperoleh. Banyaknya individu tungau parasit menentukan nilai mean's dan variansnya.

$$
S^{2}=\frac{\sum \mathrm{X}^{2}-\left(\sum \mathrm{X}\right)^{2} / \mathrm{N}}{\mathrm{N}-1}
$$

Keterangan:

$\mathrm{S}=$ Nilai varians dari semua jenis tungau yang ditemukan

$\mathrm{X}=$ Jumlah individu tungau parasit yang di temukan

$\mathrm{N}=$ Jumlah total larva Aedes sp.

Keputusan Pola Distribusi:

Pola distribusi mengelompok jika $\boldsymbol{S}^{2}>\bar{X}$

Pola distribusi acak jika $S^{2}=\bar{X}$

Pola distribusi teratur jika $\boldsymbol{S}^{\mathbf{2}}<\overline{\boldsymbol{X}}$

Tingkatan Distribusi dihitung menggunakan Indeks $\mathrm{K}^{\prime}$ distribusi binomial negatif:

$$
\mathrm{K}=\frac{X^{2}}{S^{2}-\bar{X}}
$$

Keterangan :

$\mathrm{K}=$ Indeks distribusi binomial negatif

$\overline{\boldsymbol{X}}=$ Rata-rata semua jenis tungau yang di temukan

$\mathrm{S}=$ Nilai varians dari semua jenis tungau yang di temukan

Variabel yang diamati dalam penelitian ini berupa pola distribusi atau sebaran tungau parasit pada larva Aedes sp. dan sebagai parameternya adalah nilai rata-rata setiap jenis dan variansnya. Tungau parasit yang diperoleh dianalisis berdasarkan ada tidaknya cakar (claw) pada kaki depanya, bentuk dan warna tubuh tungau, ukuran palpus, tubuh yang tersklerotisasi atau tidak, letak dan jumlah setae, bentuk genital shield dan dorsal shield tungau, sehingga dapat diketahui jenis tungau tersebut. Data yang diperoleh dianalisis menggunakan nilai rata-rata setiap jenis dan variansnya, sehingga pola distribusi dapat ditentukan. Tingkat distribusi tungau parasit dianalisis menggunakan Indeks $\mathrm{K}^{\prime}$ distribusi binomial negatif.

\section{HASIL DAN PEMBAHASAN}

Sampel larva Aedes sp. yang diperoleh dari Kelurahan Parakancanggah sebanyak 359 ekor, Kutabanjar sebanyak 366 ekor, Krandegan sebanyak 348 ekor, dan Sokanandi sebanyak 356 ekor. Pengamatan di laboratorium terhadap larva Aedes sp. di Kelurahan Parakancanggah diperoleh 13 individu tungau parasit, Kutabanjar diperoleh 7 individu, Krandegan diperoleh sebanyak 4 individu, dan Sokanandi diperoleh sebanyak 6 individu tungau parasit (Tabel 1).

Hasil pengamatan pada Tabel 1 dapat diketahui bahwa suhu udara di lokasi sampling berkisar antara 26-27 $7^{\circ} \mathrm{C}$ sehingga berpotensi untuk perkembangan nyamuk Aedes sp. Sebagaimana dikemukakan oleh Yotopranoto et al. (1998) bahwa rata-rata suhu optimum untuk pertumbuhan nyamuk adalah 25$27^{\circ} \mathrm{C}$ dan pertumbuhan nyamuk akan berhenti sama sekali bila suhu kurang dari $10^{\circ} \mathrm{C}$ atau lebih dari $40^{\circ} \mathrm{C}$. Menurut WHO (1972) dalam Yudhastuti \& Vidiyani (2005), nyamuk akan meletakkan telurnya pada temperatur sekitar $20-30^{\circ} \mathrm{C}$, telur nyamuk akan menetas menjadi larva dalam waktu 72 jam dalam temperatur udara $25-30^{\circ} \mathrm{C}$. 
Tabel 1. Jumlah Larva Aedes sp. dan Tungau Parasit yang Ditemukan pada Masing-masing Kelurahan

\begin{tabular}{|c|c|c|c|c|c|c|c|}
\hline No & Tempat & Kode & Kisaran pH & $\begin{array}{c}\text { Suhu } \\
(\mathrm{C})\end{array}$ & $\begin{array}{c}\text { Ketinggian } \\
\text { (m dpl) }\end{array}$ & $\begin{array}{c}\text { Jumlah larva } \\
\text { Aedes sp. }\end{array}$ & $\begin{array}{l}\text { Jumlah individu } \\
\text { tungau parasit }\end{array}$ \\
\hline \multirow{3}{*}{1} & \multirow{3}{*}{$\begin{array}{l}\text { Kelurahan } \\
\text { Parakancanggah }\end{array}$} & $\mathrm{A} 1$ & \multirow{3}{*}{$5-8$} & 27 & 260 & 116 & 3 \\
\hline & & A2 & & 27 & 260 & 125 & 10 \\
\hline & & A3 & & 27 & 260 & 118 & 0 \\
\hline \multirow{3}{*}{2} & \multirow{3}{*}{$\begin{array}{l}\text { Kelurahan } \\
\text { Kutabanjar }\end{array}$} & B1 & \multirow{3}{*}{$5-9$} & 26 & 245 & 125 & 0 \\
\hline & & B2 & & 26 & 245 & 116 & 7 \\
\hline & & B3 & & 27 & 245 & 125 & 0 \\
\hline \multirow{3}{*}{3} & \multirow{3}{*}{$\begin{array}{l}\text { Kelurahan } \\
\text { Krandegan }\end{array}$} & $\mathrm{C} 1$ & \multirow{3}{*}{$6-8$} & 26 & 280 & 116 & 1 \\
\hline & & $\mathrm{C} 2$ & & 26 & 280 & 115 & 3 \\
\hline & & C3 & & 26 & 280 & 117 & 0 \\
\hline \multirow{4}{*}{4} & \multirow{4}{*}{$\begin{array}{l}\text { Kelurahan } \\
\text { Sokanandi }\end{array}$} & D1 & \multirow{4}{*}{$6-7$} & 27 & 290 & 126 & 2 \\
\hline & & D2 & & 27 & 290 & 115 & 1 \\
\hline & & D3 & & 26 & 290 & 115 & 3 \\
\hline & & & & & Total & 1429 & 30 \\
\hline
\end{tabular}

Keterangan :

A1 = pengambilan sampel di RW II

$\mathrm{B} 1$ = pengambilan sampel di RW I

$\mathrm{C} 1$ = pengambilan sampel di RW

D1 = pengambilan sampel di RW III
$\mathrm{A} 2$ = pengambilan sampel di RW III

$\mathrm{B} 2$ = pengambilan sampel di RW V

$\mathrm{C} 2$ = pengambilan sampel di RW V

D2 = pengambilan sampel di RW IV
A3 = pengambilan sampel di RW V

B3 = pengambilan sampel di RW VI

C3 = pengambilan sampel di RWVII

D3 = pengambilan sampel di RW VI

Tabel 2. Familia Tungau Parasit yang Ditemukan pada Masing-masing Kelurahan di Kabupaten Banjarnegara

\begin{tabular}{llcccc}
\hline \multirow{2}{*}{ No } & \multirow{2}{*}{ Tempat } & \multicolumn{3}{c}{ Familia tungau yang ditemukan } \\
\cline { 3 - 6 } & Histiostomatidae & Pionidae & Hydrypantidae & Hydrachnidae & Arrenuridae \\
\hline 1 & Kelurahan Parakancanggah & 4 & 2 & 6 & 1 \\
2 & Kelurahan Kutabanjar & 3 & 0 & 1 & 2 \\
3 & Kelurahan Krandegan & 1 & 1 & 2 & 0 \\
4 & Kelurahan Sokanandi & 4 & 0 & 1 & 1 \\
\hline & Jumlah & 12 & 3 & 10 & 0 \\
\hline
\end{tabular}

Selain suhu, ketinggian tempat juga berpengaruh terhadap perkembangbiakan nyamuk Aedes sp. Nyamuk Aedes sp. dapat hidup dan berkembangbiak sampai ketinggian 1.000 meter dari permukaan air laut, di atas ketinggian 1.000 meter tidak dapat berkembangbiak, karena pada ketinggian tersebut suhu udara terlalu rendah sehingga tidak memungkinkan bagi kehidupan nyamuk tersebut (Syarifah, 2007). Ketinggian tempat di lokasi sampling berkisar antara 245-290 meter di atas permukaan air laut sehingga masih memenuhi syarat bagi perkembangbiakan nyamuk Aedes sp.

Derajat keasaman merupakan salah satu faktor yang mempengaruhi perkembangbiakan larva Aedes sp. yang ada pada air di kontainer. Perkembangan larva Aedes sp. pada air di kontainer bisa tetap berlangsung sampai menjadi nyamuk dewasa pada kisaran $\mathrm{pH} 4$ sampai dengan $\mathrm{pH} 10$ dan optimum pada pH 7. Laju pertumbuhan $A$. aegypti menurun seiring peningkatan $\mathrm{pH}$ meskipun volume air tempat berkembang biak tetap jumlahnya (Thomas et al., 2004). Hasil pengukuran pH pada setiap titik pengambilan sampel dalam penelitian ini masih dalam kisaran toleransi perkembangbiakan nyamuk Aedes sp yaitu berkisar antara 5-9. Kesesuaian suhu, ketinggian tempat dan $\mathrm{pH}$ pada lokasi pengambilan sampel tersebut menyebabkan jumlah larva nyamuk Aedes sp. yang didapat dari keempat lokasi sampling relatif banyak.

Hasil identifikasi terhadap ke 30 individu tungau parasit yang ditemukan diketahui tungau parasit tersebut termasuk ke dalam lima familia yaitu familia Pionidae, familia Histiostomatidae, familia Hydryphantidae, familia Hydrachnidae dan familia Arrenuridae (Tabel 2). Hasil penelitian menujukan bahwa familia tungau parasit Histiostomatidae merupakan familia yang paling banyak ditemukan pada setiap larva Aedes sp. yang diamati yaitu 12 individu. Familia Histiostomatidae yang ditemukan berasal dari semua lokasi pengambilan sampel yang ada di 4 kelurahan. Hal ini sesuai dengan pendapat Mullen, et al. (2007) yang menyatakan bahwa familia Histiostomatidae mampu hidup bebas (free living mites), hidup diberbagai habitat air, serta mampu bertahan hidup pada substrat dengan kandungan bahan organik yang tinggi.

Berdasarkan pengamatan secara langsung, familia Histiostomatidae mempunyai bentuk tubuh oval, palpus pendek dan terdapat segment pada ujung palpus, mempunyai satu cakar (claw) pada kaki depannya, pada bagian idiosomanya tidak tersklerotisasi secara jelas, genital shieldnya berbentuk oval, pada sepasang kaki pertama terdapat dua pasang setae, sedangkan pada sepasang kaki ke empatnya hanya terdapat sepasang setae. Familia Histiostomatidae mempunyai ciri-ciri tubuh yang lunak terutama pada bagian idiosomanya, mempunyai setae yang panjang pada bagian dorsalnya dengan pedipalpus yang pendek, mempunyai 1 cakar pada tarsusnya (Harvey, 1998 dalam Snell \& Heath, 2010). Qin (1996), menyatakan bahwa tungau familia Histiostomatidae mempunyai kisaran panjang tubuh 
antara 414-700 $\mu \mathrm{m}$, genital shieldnya berbentuk oval dan pada pseudoanalnya terdapat tiga pasang setae. Sepasang setae ditemukan pada kaki ke empatnya. Setae renang pada kakinya digunakan untuk mencari mangsa. Selain untuk mencari mangsa, pada sepasang kaki pertamanya juga termodifikasi untuk menancapkan diri ke tubuh inang saat menghisap cairan dari inang ataupun pada saat istirahat.

Familia Arrenuridae merupakan familia yang jumlahnya paling sedikit ditemukan dilokasi sampling yaitu satu individu. Hal ini karena pengambilan sampel sebagian besar barada di tempat penampungan air yang tidak berhubungan langsung dengan tanah dan $\mathrm{pH}$ rata-rata lokasi sampling melebihi atau kurang dari $\mathrm{pH}$ netral. Smith, et al. (2001) menyatakan bahwa Arrenuridae lebih banyak ditemukan di tempat-tempat yang langsung berhubungan dengan tanah dengan kondisi $\mathrm{pH}$ air yang netral. Morfologi tungau parasit tersebut diketahui bahwa familia Arrenuridae memiliki ciri-ciri berbadan keras, berwarna coklat, palpus pendek, shield pada bagian dorsal dan ventral yang tersklerotisasi sempurna dan berbentuk bulat, genital shieldnya juga berbentuk bulat. Smit (2010) menyatakan bahwa tungau familia Arrenuridae berbadan keras, berwarna coklat, dorsal shieldnya berbentuk bulat. Selain itu menurut Pluchino (1984) yang menyatakan bahwa Arrenuridae merupakan tungau yang memiliki shield pada dorsal dan ventralnya, dan juga tedapat bagian yang berbentuk seperti sayap.

Tungau familia Hydryphantidae juga merupakan tungau parasit yang menjadikan larva nyamuk sebagai salah satu makananya. Familia Hydrypantidae yang ditemukan pada penelitian ini berjumlah 10 individu yang sebagian besar berasal dari genangan air pada potongan lubang bambu. Hal ini sesuai dengan pendapat Williams \& Proctor (2002) yang menyatakan bahwa familia Hydryphantidae merupakan parasit pada larva nyamuk yang hidup di dalam air yang terdapat pada lubang-lubang pohon. Tungau familia Hydryphantidae mempunyai ciri morfologi tubuh berwarna merah kecoklatan, berbadan keras, bentuk tubuh oval, palpus panjang dan terdapat 5 segmen, mempunyai satu cakar pada sepasang kaki pertamanya, sedangkan kaki belakangnya berbentuk gepeng hal ini karena berfungsi untuk mendayung pada saat renang. Dorsal shieldnya sedikit cekung, setae pada kaki renangnya hanya ditemukan pada sepasang kaki pertamanya saja. Hal ini sesuai dengan pernyataan Tuzovsky (2008), bahwa tungau familia Hydryphantidae berwarna merah, tubuh oval, dorsal shield terbagi atas 3 bagian, palpus panjang, bagian anal kecil, kaki terdiri atas 3 segmen dan terdapat setae renang pada sepasang kaki pertamanya, mempunyai cakar pada kaki renangnya yang digunakan untuk mengaitkan tubuhnya ke tubuh inang, terdapat 3-5 segment pada bagian palpusnya. Hasil penelitian Proctor (2006) dalam Gunawan (2010), menyatakan bahwa familia Hydryphantidae mempunyai setae renang pada bagian kaki yang terletak pada segmen distal dan terdapat piringan di antara kedua mata.

Jenis tungau yang didapat lainnya yaitu familia Hydrachnidae. Familia Hydrachnidae ini ditemukan pada bak kamar mandi dengan jumlah yaitu empat individu. Hal ini sesuai dengan pendapat Smith dan Cook (1991) dalam Snell \& Heath (2010), familia Hydrachnidae dapat dijumpai dalam jumlah yang banyak pada perairan tawar seperti kolam dari pada tempat-tempat yang lainnya. Pengamatan pada familia Hydrachnidae menunjukan hasil bahwa tungau tersebut memiliki ciri-ciri tubuh berbentuk oval dan berwarna merah kecoklatan serta memiliki mempunyai cakar atau claw pada 2 pasang kaki depannya. Menurut Smith and Cook (1991) dalam Snell and Heath (2010), family Hydrachnidae disebut tungau air merah, karnifora dan dapat bersifat parasit bagi serangga perairan. Ukurannya dapat mencapai 6 mm dan hidup di perairan terbuka. Segmen ke-3 dari palpus terlihat memanjang daripada tibia palpus, biasanya terdiri dari satu atau dua lempeng diantara mata. Coxae ke-4 lebih melebar daripada coxae yang lain. Family Hydrachnidae pada umumnya memiliki ukuran coxae besar dan berwarna merah (Proctor, 2006 dalam Gunawan, 2010). Sedangkan ciri lain dari familia Hydrachnidae yaitu mempunyai tonjolan seperti cakar yang berfungsi sebagai pencengkram rambut dari inangya (Elmer \& Noble, 1982).

Selain keempat familia tersebut, tungau parasit familia Pionidae juga ditemukan pada lokasi sampling dengan jumlah tiga individu. Tungau parasit familia Pionidae yang ditemukan relative sedikit dibandingkan dengan familia lainya, hal itu disebabkan karena familia Pionidae yang ditemukan saat penelitian sedang berlangsung pada musim peralihan antara musim kemarau dan musim hujan (pancaroba). Familia tungau Pionidae lebih sulit ditemukan pada saat musim kemarau jika dibandingkan dengan musim hujan (Panduningrum, 2009).

Berdasarkan pengamatan morfologi tungau parasit tersebut diketahui bahwa familia Pionidae mempunyai ciri tubuh berbentuk bulat, bulat memanjang dan tubuhnya lunak. Memiliki tubuh berwarna merah tua, memiliki 2 pengait terseklerotiasi di depan palpus dan memiliki palpus yang sederhana. Hal tersebut sesuai dengan pernyataan Boyaci \& Ozcan (2005) yang menyatakan bahwa tungau familia Pionidae pada bagian palpusnya berbentuk konveks, terdapat 2 pengait yang tersklerotisasi, mempunyai setae pada bagian palpus yang berfungsi sebagai pendeteksi keberadaan mangsa serta mempunyai setae renang pada setiap kakinya.

Hasil analisis distribusi geografis terhadap tungau parasit yang menginfeksi larva Aedes sp. dari Kelurahan Parakancanggah, Kelurahan Kutabanjar, Kelurahan Krandegan dan Kelurahan Sokanandi menunjukkan bahwa tungau tersebut terdistribusi secara teratur. 
Tabel 3. Distribusi Geografis Tungau Parasit yang Menginfeksi Larva Aedes sp. dari Kelurahan Parakancanggah, Kutabanjar, Krandegan dan Sokanandi

\begin{tabular}{clcccc}
\hline No & Kelurahan & Mean & Varians & Pola distribusi & Derajat distribusi (K) \\
\hline 1 & Parakancanggah & 0,0362 & 0,035 & Teratur & 1,092 \\
2 & Kutabanjar & 0,0191 & 0,0188 & Teratur & 1,216 \\
3 & Krandegan & 0,0115 & 0,0114 & Teratur & 1,3225 \\
4 & Sokanandi & 0,0169 & 0,0166 & Teratur & 0,952 \\
\hline
\end{tabular}

Selain pola distribusi, berdasarkan nilai mean's dan varians pada masing-masing lokasi, maka dapat diketahui Kelurahan Krandegan mempunyai nilai $\mathrm{K}$ tertinggi (Tabel 3).

Hasil analisis distribusi geografis di masing-masing kelurahan lokasi penelitian menunjukkan bahwa nilai rata-rata individu tungau parasit pada larva nyamuk Aedes sp. lebih besar daripada nilai variansnya yang artinya pola distribusi tungau pada masing-masing lokasi penilitian memiliki pola distribusi teratur. Lokasi pengambilan sampel yang jaraknya tidak lebih dari 400 meter antara tempat yang satu dengan tempat yang lainnya menyebabkan pola distribusi dari tungau parasit di daerah tersebut menjadi teratur, diduga terkait dengan distribusi dari Aedes sp yang merata di ke empat kelurahan tersebut. Hal ini didukung oleh pernyataan Ambarwati, et al. (2006) bahwa nyamuk Aedes sp. mempunyai kemampuan terbang sejauh 400 meter, sehingga tungau parasit dapat terdistribusi melalui nyamuk tersebut secara teratur ke beberapa tempat perindukan nyamuk.

Lebih tingginya tingkatan Distribusi (K) di Kelurahan Krandegan di banding ketiga kelurahan lainya. Tingginya tingkatan Distribusi di Kelurahan Krandegan di banding ketiga kelurahan lainya diduga lebih teraturnya pola distribusi di kelurahan tersebut dibandingkan dengan pola distribusi tungau parasit di wilayah sampling yang lain yaitu Kelurahan Parakancanggah, Kelurahan Kutabanjar dan Kelurahan Sokanandi. Pengambilan sampel pada tempat-tempat perindukan nyamuk yang terbatas yakni pada bekas lubang potongan bambu, kaleng bekas, kamar mandi maupun kolam yang mejadi habitat dari tungau parasit juga diduga dapat menyembabkan pola distribusi dari tungau parasit di daerah tersebut menjadi lebih teratur. Pernyataan tersebut sesuai dengan Smith (1988), menyatakan bahwa lebih teratur pola distribusi pada tungau parasit terjadi ketika tungau parasit hidup pada habitat yang terbatas. Selain faktor-faktor tersebut, jarang tersedianya tempat perindukan berkaitan dengan peralihan musim kemarau dan penghujan saat penelitian, dengan demikian populasi Aedes sp. belum mengalami puncak populasi, hal tersebut diduga menjadi faktor lain yang menyebabkan teraturnya distribusi tungau parasit di keempat kelurahan tersebut.

\section{KES I M P U L A N}

Familia tungau parasit yang ditemukan di daerah endemis demam berdarah dengue di Kabupaten Banjarnegara adalah Histiostomatidae, Pionidae,
Hydrypantidae, Hydrachnidae, dan Arrenuridae. Pola distribusi tungau parasit pada larva nyamuk Aedes sp. di Kelurahan Parakancanggah, Krandegan, Krandegan dan Sokanandi bersifat teratur dengan tingkatan Distribusi (K) tertinggi di Kelurahan Krandegan yaitu 1,3225

\section{DAFT AR REFERENSI}

Ambarwati SD, Astuti D. 2006. Fogging sebagai upaya untuk memberantas nyamuk penyebar demam berdarah di Dukuh Tuwak Desa Gonilan, Kartasura, Sukoharjo. Warta. 9:130-138.

Arrimoro FO. 2010. Microhabitat preference, diversity and ecology of aquatic mites in a municipal stream in the Niger Delta. Journal of Applied Biosciences. 27:1687-1696

Boyaci YO, Ozcan M. 2005. A new species of Hydryphantes C.L.Koch, 1841 (Hydryphantidae, Hydrachnellae, Acari) for the Turkish fauna. Turkey Journal Zoology. 29:39-43.

Budianto, B.H. 2007. Keragaman tungau air pada stadium pradewasa nyamuk Aedes aegypti [Penelitian Mandiri]. Fakultas Biologi Universitas Jenderal Soedirman-Purwokerto.

Deshmukh, I. 1992. Ekologi dan biologi tropika. Jakarta: Yayasan Obor Indonesia.

Elmer RN, Noble GA. 1982. Parasitologi biologi parasit hewan. [diterjemahkan oleh Wardiarto dan N. Soeripto. 1989]. Yogyakarta: Gadjah Mada University Press.

Gunawan LH. 2010. Distribusi geografis tungau parasit nyamuk Aedes sp. di daerah endemis demam berdarah dengue di Kabupaten Banyumas [skripsi]. Fakultas Biologi Universitas Jenderal Soedirman-Purwokerto.

Mullen, Gary R. 1975. Acarine parasites of mosquitoes I. A critical review of all known records of mosquitoes parasitized by Mites. Journal of Medical Entomology. 12:27-36.

Mullen GR, Ahmed MA, Rafiaa R, Ahmed A, Oconnor BM, Alkhalife SI, Roland RD. 2007. A human case of otoacariasis involving a Histiostomatid Mite (Acari: Histiostomatidae). American Journal Tropical Medical Hygiene. 76:967-971.

Nilamsari CI. 2005. Pengaruh lingkungan terhadap perkembangan penyakit malaria dan demam berdarah dengue [makalah pribadi]. Falsafah Sains (PPS 702) Sekolah Pasca Sarjana Institut Pertanian Bogor-Bogor.

Panduningrum, T. 2009. Kemampuan menginfeksi tungau parasit pada larva nyamuk Aedes sp. di Kabupaten Banyumas [skripsi]. Fakultas Biologi Universitas Jenderal Soedirman-Purwokerto.

Pluchino ES. 1984. Guide to the common water Mite Genera of Florida. Florida: Department of Environmental Regulation Orlando.

Qin TK. 1996. The astigmatid mite Histiostoma feroniarum (Acari: Astigmata, Histiostomatidae) in New Zeland. New Zeland Entomologist. 19:1-5.

Sabatino AD, Boggero A, Miccoli FP, Cicolani B. 2004. Diversity, distribution and ecology of water mites (Acari: Hydrachnidia and Halacaridae) in high Alpine lakes (Central Alps, Italy). Experimental and Applied Acarology. 34:199-210.

Smit, H. 2010. Two new spesies of the genus Arrenurus from Pohnpei, Federal State of Micronesia (Acari, Hydrachnidia, Arrenuridae). Zootaxa. 2606:50-54

Smith BP. 1988. Host parasite interaction and impact of larval water mites on insect. Annual Review of Entomology. 33: 487-507.

Smith BP, Mciver SB. 1983. The patterns of mosquito emergence (Diptera: Culicidae; Aedes spp.): their influence on host selection by parasitic mites (Acari: Arrenuridae; Arrenurus spp.). Canada Journal Zoology. 62:1106-1113.

Smith IM, Cook DR, Smith BP. 2001. Water mites (Hydrachnida) and other arachnids. In : Thorp, J.H and A.P. Covich (Eds.). 2001. 
Ecology and classification of North American freshwater invertebrates. Proceedings of the 12th International Congress: 551-659. California: Academic Press.

Snell AE, Heath ACG. 2010. Parasitism of mosquitoes (Diptera: Culicidae) by larvae of Arrenuridae and Microtrombidiidae (Acari: Parasitengona) in the Wellington region, New Zealand. New Zealand Journal Zoology. 33:9-15.

Sukamto. 2007. Studi karakteristik wilayah dengan kejadian DBD di Kecamatan Cilacap Selatan Kabupaten Cilacap [tesis]. Magister Kesehatan Lingkungan Universitas Diponegoro-Semarang.

Supartha IW. 2008. Pengendalian terpadu vektor virus demam berdarah dengue, Aedes aegypti (Linn.) dan Aedes albopictus (Skuse)(Diptera: Culicidae); [diakses tanggal 6 September 2011]. Diambil dari http://dies.unud.ac.id/.

Syarifah, U. 2007. Analisis beberapa faktor yang berhubungan dengan keberadaan jentik di Rw III Kelurahan Tlogosari Kulon Kecamatan Pedurungan Kota Semarang [skripsi]. Fakultas Ilmu Keolahragaan Universitas Negeri Semarang- Semarang

Thomas MC, Benjaminand JF, Susanna KR. 2004. Differences in the effects of salinity on larval growth and developmental programs of a freshwater and a euryhaline mosquito species (Insecta: Diptera, Culicidae). Journal of Experimental Biology. 207:22892295.

Tuzovsky VP. 2008. A new record of the water mite Hydryphantes tenuipalpis Thon (Acariformes: Hydryphnatidae) for Russia. Acarina. 16:57-64.

Williams CR, Proctor HC. 2002. Parasitism of mosquitoes (Diptera: Culicidae) by larva mites (Acari: Parasitengona) in Adelaide, South Australia. Australia Journal Entomology. 41:161-163.

Williams CR, Proctor HC. 2002. Parasitism of mosquitoes (Diptera: Culicidae) by larval mites (Acari: Parasitengona) in Adelaide, South Australia. Australia Journal Entomology. 41:161-163.

Yotopranoto SS, Subekti, Rosmanida, Sulaiman. 1998. Dinamika populasi vektor pada lokasi dengan kasus demam berdarah dengue yang tinggi di Kotamadya Surabaya. Majalah Kedokteran Tropis Indonesia. 9:1-2.

Yudhastuti, R. dan A. Vidiyani. 2005. Hubungan kondisi lingkungan, kontainer, dan perilaku masyarakat dengan keberadaan jentik nyamuk Aedes aegypti di daerah endemis demam berdarah dengue Surabaya. Jurnal Kesehatan Lingkungan. 1:170-183. 